\title{
EFEKTIVITAS TERAPI SPRITUAL EMOTIONAL FREEDOM TECHNIQUE (SEFT) TERHADAP PENURUNAN TEKANAN DARAH PADA PENDERITA HIPERTENSI
}

\author{
Murni \\ Program Studi S1 Keperawatan \\ Sekolah Tinggi Ilmu Kesehatan Al-Insyirah Pekanbaru
}

\section{ABSTRACT}

Spritual emotional freedom technique (SEFT) is technique of relaxation mind-body therapy. SEFT is a merging technique of the body's energy system (energy medicine) and spiritual therapy using tapping method on the body specific points. The aims of this research is to determine the effectiveness of spritual emotional freedom technique therapy to decrease blood pressure in hipertensive patients in Puskesmas Harapan Raya Pekanbaru. Design of the research used quasy experiment. The sample of research were 60 peoples, 30 as experimental group and 30 as control group. The technique for sampling used purposive sampling. Data Analysis was used dependent and independent sample $T$ test. The results showed that there was significant influence between therapy SEFT with decrease blood pressure in hypertensive patients with $p<0.05(p=0.000)$. It is suggested to use SEFT therapy as an alternative treatment of hypertension.

Keyword s: Spritual emotional freedom fechnique, blood pressure, hypertension

\section{PENDAHULUAN}

Prevalensi terhadap penyakit tidak menular di Indonesia mengalami peningkatan. Kecendrungan meningkatnya prevalensi penyakit tidak menular salah satunya adalah hipertensi yang disebut sebagai the silent killer. Jumlah penderita hipertensi di dunia mengalami peningkatan setiap tahun. Menurut survei yang dilakukan oleh organisasi kesehatan dunia (WHO) tahun 2011 menyebutkan bahwa di seluruh dunia sekitar 972.000 .000 orang atau $26,4 \%$ penduduk dunia mengidap penyakit tersebut dengan perbandingan $26,6 \%$ pria dan $26,1 \%$ wanita. Angka ini kemungkinan akan meningkat menjadi 29,2 \% ditahun 2025. Jumlah penderita di negara maju berkisar 333.000.000 jiwa dan 639.000.000 jiwa di negara berkembang. Hipertensi juga membunuh hampir 8.000.000 orang setiap tahun, dimana hampir 1,5 juta adalah penduduk Asia Tenggara.

Hasil Riset Kesehatan Dasar tahun 2013 prevalensi hipertensi di Indonesia berdasarkan hasil pengukuran pada umur $\geq 18$ tahun sebesar 25,8 persen dan $63,2 \%$ kasus hipertensi di masyarakat tidak terdiagnosis. Angka kejadian hipertensi menjadi penyebab kematian sebesar $6,8 \%$. Banyak faktor yang dapat menyebabkan terjadinya hipertensi, seperti kurangnya sarana dan prasaranan dalam penanggulangan hipertensi. Tingginya angka hipertensi dipengaruhi oleh kebiasaan merokok, kurangnya aktifitas, pola makan yang tidak sehat, obesitas dan stres.

Peningkatan jumlah penderita hipertensi juga ditemukan di Pekanbaru Provinsi Riau. Berdasarkan data Dinas Kesehatan Kota Pekanbaru tahun 2014, pada tahun 2012 jumlah penderita tersebut sebanyak 19.878 orang, meningkat menjadi 24.509 orang pada 
tahun 2013, dan kembali turun pada tahun 2014 menjadi 20.601 orang. Salah satu Kecamatan di Pekanbaru, Kecamatan Bukit Raya memiliki jumlah penderita hipertensi terbanyak pada tahun 2014 yaitu di Wilayah Kerja Puskesmas Harapa Harapan Raya Kota Pekanbaru yaitu sebanyak 3.683 orang (Dinkes, 2014).

Hipertensi merupakan penyakit yang tidak dapat disembuhkan sehingga memerlukan penanganan yang rumit dan sulit. Penyakit hipertensi juga menyebabkan komplikasi yang serius apabila tidak mendapatkan penanganan yang serius. Penyakit mata, jantung, ginjal dan otak merupakan komplikasi-komplikasi yang mungkin ditimbulkan oleh penyakit hipertensi (Smeltzer \& Bare, 2004).

Pengobatan hipertensi dibagi menjadi dua yaitu pengobatan secara farmakologis dan non farmakologis. Secara farmakologis pengobatan hipertensi merupakan pengobatan jangka panjang sehingga bila suatu pola pengobatan dipilih, maka terapi dengan menggunakan obat akan terus bertambah. Setelah penghentian mendadak dari obat antihipertensi, tekanan darah biasanya naik lebih tinggi dan kebutuhan obat akan terus meningkat (Braverman \& Braverman, 2008).

Pengobatan farmakologis memiliki banyak efek samping negatif. Sekitar 85\% penderita hipertensi melaporkan terdapat efek samping yang mengganggu setelah mengkonsumsi obat-obatan antihipertensi. Menurut laporan dari American Medical Association (AMA), American Heart Association (AHA), dan National Institute of Health (NIH) menunjukkan bahwa mengobati kolesterol dan tekanan darah tinggi dengan obat yang saat ini digunakan dapat menurunkan gairah seksual, mempercepat penuaan organ-organ utama (jantung, otak, paru-paru, dan ginjal), serta dapat memperpendek hidup lebih dari 16 tahun, khususnya bila berat badan lebih dari 4,5 kg di atas normal (Braverman \& Braverman, 2008).

Terapi komplementer merupakan salah satu pengobatan non-farmakologi untuk mengatasi penyakit hipertensi terapi komplementer yang dapat dipilih sebagai alternatif pengobatan hipertensi adalah terapi Spritual Emosional Freedom Technique (SEFT). Terapi SEFT merupakan terapi relaksasi dan mind-body therapy. SEFT merupakan teknik penggabungan dari sistem tubuh (energy medicine) dan terapi spritual dengan menggunakan metode tapping pada beberapa titik tertentu pada tubuh. Terapi SEFT bekerja dengan prinsip merangsang titik- titik kunci pada sepanjang 12 jalur energi (energy meridian) tubuh. Teknik SEFT menggunakan unsur spritual, dan cara yang digunakan lebih aman, lebih mudah, serta lebih cepat dan lebih sederhana (Zainuddin, 2009).

Puskesmas Harapan Raya merupakan salah satu puskesmas yang ada di Kota Pekanbaru. Data yang diperoleh dari Puskesmas Harapan Raya Kecamatan Bukit Raya penderita hipertensi pada tahun 2015 menduduki peringkat ke-1 dari 20 puskesmas yang ada di Kota Pekanbaru sebanyak 3.683 orang. Sedangkan penderita Penderita hipertensi pada bulan september 2016 masih cukup tinggi yaitu sebanyak 325 orang.

Berdasarkan studi pendahuluan yang dilakukan penulis di wilayah kerja Puskesmas Harapan Raya Pekanbaru dengan melakukan pengukuran tekanan darah terhadap 10 orang, ternyata 7 dari 10 orang masih mengalami hipertensi. Usaha yang dilakukan belum begitu efektif untuk menurunkan tekanan darah. Peneliti juga menanyakan tentang terapai SEFT kepada 10 orang tersebut. Hasilnya dari 10 orang tersebut semuanya belum pernah melakukan terapi SEFT. 


\section{METODOLOGI PENELITIAN}

Jenis penelitian ini merupakan penelitian Analitik Kuantitatif dengan menggunakan desain penelitian Quasy Eksperiment yaitu penelitian dengan rancangan pretest posttest with control grup design. Pada rancangan ini kelompok eksperimen diberi perlakuan berupa terapi SEFT dalam waktu \pm 20 menit, sedangkan kelompok kontrol tidak diberi perlakuan. Pengukuran dilakukan sebelum perlakuan (pretest) dan sesudah perlakuan (postest).

Sampel pada penelitian ini adalah penderita hipertensi di Wilayah Kerja Puskesmas Harapan Raya Kecamatan Bukit Raya. Pada penelitian ini pengambilan sampel menggunakan purposive Sampling. Peneliti mengambil sampel sebanyak 60 orang dengan rincian 30 untuk kelompok eksperimen dan 30 untuk kelompok kontrol.

Adapun kriteria inklusi untuk sampel penderita hipertensi ini adalah: 1) Penderita hipertensi yang ada di Puskesmas Harapan Raya Pekanbaru; 2) Penderita hipertensi yang tidak mengkonsumsi obat anti hipertensi; 3) Penderita hipertensi yang tidak menderita penyakit lain selain hipertensi; 4) Penderita hipertensi yang tidak sedang menjalani terapi komplementer lainnya (latihan otot progresif, terapi musik, refleksiologi dsb); 5) Umur berkisar 30-50 tahun; 6) Penderita hipertensi tidak merokok; 7) Penderita hipertensi yang bersedia menjadi responden; 8) Berjenis kelamin laki-laki; 9) Beragama Islam.

Adapun analisisis data yang digunakan dalam penelitian ini adalah univariat dan bivariat. Analisis univariat dilakukan terhadap tiap variabel dari hasil penelitian. Analisis digunakan untuk mendapatkan gambaran tentang distribusi tekanan darah dalam bentuk Mean atrial presure (MAP) sebelum dan sesudah diberikan terapi SEFT pada kelompok eksperimen dan kelompok kontrol.
Pada analisis univariat dilakukan test of normality untuk menilai data yang berdistribusi normal. Uji hemogenitas menggunakan independent sample T-test pada kelompok eksperimen dan kelompok kontrol sebelum perlakuan (pretest).

Analisis Bivariat menggunakan dependent sample T-test. Untuk melihat pengaruh perlakuan terhadap kelompok eksperimen sebelum dan sesudah pemberian terapi. Selanjutnya dilakukan independent sampel T-test. Untuk melihat perbedaan penurunan tekanan darah antara kelompok eksperimen dan kelompok kontrol setelah pemberian perlakuan (pretest). Pemberian terapi dinyatakan ada pengaruh atau efektif terhadap penurunan tekanan darah pada penderita hipertensi jika hasil ukur menunjukkan nilai $p$ value $<$ dari $(0,05)$.

\section{HASIL PENELITIAN}

\section{A. Analisis Univariat}

a. Sebelum Diberi Terapi

Tabel 1. Distribusi Tekanan Arteri RataRata (MAP) Sebelum Diberi Terapi SEFT Pada Kelompok Eksperimen Dan Kelompok Kontrol

\begin{tabular}{ccc}
\hline Variabel & Jumlah & Mean \\
\hline MAP sebelum diberi & & \\
terapi & & \\
Ekserimen & 30 & 118,37 \\
Kontrol & 30 & 120,93 \\
\hline
\end{tabular}

Tabel 1 didapatkan MAP sebelum diberi terapi pada kelompok eksperimen adalah 118,37, sedangkan pada kelompok kontrol adalah 120,93 .

\section{b. Sesudah Diberi Terapi}

Tabel 2. Distribusi Tekanan Arteri RataRata (MAP) Sesudah Diberi Terapi SEFT Pada Kelompok Eksperimen Dan Kelompok Kontrol 


\begin{tabular}{ccc}
\hline Variabel & Jumlah & Mean \\
\hline MAP sesudah diberi terapi & & \\
Ekserimen & 30 & 101,23 \\
Kontrol & 30 & 120,23 \\
\hline
\end{tabular}

Tabel 2 didapatkan MAP sesudah diberi terapi pada kelompok eksperimen adalah 101,23, sedangkan pada kelompok kontrol adalah 120,23.

\section{B. Analisis Bivariat}

a. Uji T dependent

Tabel 3. Perbandingan Tekanan Arteri

Rata-Rata (MAP) Sebelum Dan

Sesudah Diberi Terapi SEFT

Pada Kelompok Eksperimen

\begin{tabular}{lcccc}
\hline Variabel & N & Mean & SD & $\mathbf{P}_{\text {value }}$ \\
\hline $\begin{array}{l}\text { MAP kelompok } \\
\text { eksperimen }\end{array}$ & & & & \\
$\begin{array}{l}\text { Pengukuran I } \\
\text { Pengukuran II }\end{array}$ & 30 & 118,37 & 4,937 & 0,066 \\
& 30 & 101,23 & 4,297 & 0,000 \\
\hline
\end{tabular}

Tabel 3 didapatkan MAP pengukuran pertama pada kelompok eksperimen adalah 118,37 (SD 4,937) dan MAP pengukuran kedua diberikan terapi SEFT pada kelompok eksperimen adalah 101,23 (SD 4,297). Hasil uji statistik didapatkan $p$ value $=0,000$ dimana lebih kecil dari alpha $(p<0,05)$. Hal ini menunjukkan ada penurunan yang signifikan antara MAP pengukuran pertama dan pengukuran kedua setelah diberikan terapi SEFT pada kelompok eksperimen. Dengan demikian dapat disimpulkan bahwa terapi SEFT dapat efektif dalam menurunkan tekanan darah pada penderita hipertensi.

Tabel 4. Perbandingan Tekanan Arteri Rata-Rata (MAP) Sebelum Dan Sesudah Diberi Terapi SEFT Pada Kelompok Kontrol

\begin{tabular}{lcccc}
\hline Variabel & N & Mean & SD & P value \\
\hline MAP kelompok & & & & \\
kontrol & & & & \\
Pengukuran I & 30 & 120,93 & 5,638 & 0,066 \\
Pengukuran II & 30 & 120,23 & 5,469 & 0,141 \\
\hline
\end{tabular}

Tabel 4 didapatkan MAP pengukuran pertama pada kelompok kontrol adalah 120,93 (SD 5,638) dan MAP pengukuran kedua adalah 120,23 (SD 5,469). Hasil uji statistik didapatkan $p$ value $=0,141$ dimana lebih besar dari alpha $(p>0,05)$. Hal ini menunjukkan tidak ada penurunan yang signifikan antara pengukuran pertama dan pengukuran kedua pada kelompok kontrol.

b. Uji T independent

Tabel 5. Perbandingan Tekanan Arteri Rata-Rata (MAP) Sesudah Diberi Terapi SEFT Pada Kelompok Eksperimen Dan Kelompok Kontrol

\begin{tabular}{llllll}
\hline Kelompok & $\mathbf{N}$ & Mean & SD & $\mathbf{T}$ & $\mathbf{P}_{\text {value }}$ \\
\hline Eksperimen & 30 & 101,23 & 4,297 & 14,963 & \multirow{2}{*}{0,000} \\
Kontrol & 30 & 120,23 & 5,469 & 14,963 & \\
\hline
\end{tabular}

Berdasarkan tabel 5 didapatkan MAP sesudah diberikan terapi SEFT pada kelompok eksperimen adalah 101,23 (SD 4,297) dan pada kelompok kontrol adalah 120,23 (SD 5,496). Hasil uji statistik didapatkan $p$ value $=0,000$ dimana lebih kecil dari alpha $(p<0,05)$. Hal ini menunjukkan adanya perbedaan yang signifikan MAP setelah diberikan terapi SEFT antara kelompok eksperimen dan kelompok kontrol.

\section{PEMBAHASAN}

Berdasarkan hasil analisis univariat MAP, sesudah diberi terapi pada kelompok eksperimen adalah 101,23 dan pada kelompok kontrol adalah 120,23. Hal ini menunjukkan bahwa pada kelompok eksperimen mengalami penurunan yang signifikan setelah dilakukan terapi SEFT.

Berdasarkan hasil analisis bivariat Uji T-Dependen menunjukkan bahwa ada perbedaan MAP yang signifikan sebelum dan sesudah diberikan terapi SEFT pada kelompok 
eksperimen ( $\mathrm{P}$ value <0,05) yaitu $p$ value 0,000. Hal tersebut dikarenakan efek dari terapi SEFT dapat menurunkan tekanan darah pada penderita hipertensi.

\section{Berdasarkan Uji T-Independen} diperoleh nilai $p$ value $<\alpha 0,05(0,000<0,05)$. Hal ini menunjukkan bahwa terjadi perbedaan yang signifikan antara MAP pada kelompok eksperimen dan kelompok kontrol sesudah diberikan perlakuan sehingga dapat disimpulkan terapi SEFT dapat membantu menurunkan tekanan darah pada penderita hipertensi. Sebagian besar responden pada kelompok eksperimen mengatakan bahwa setelah melakukan terapi SEFT mendapatkan ketenangan dan sakit kepala serta ketegangan otot pada tengkuk yang mereka alami berkurang bahkan hilang. Seseorang yang dalam kondisi tertekan hormon adrenalin dan kortisol akan dilepaskan ke dalam darah sehingga menjadi peningkatan tekanan darah (Widharto, 2007). Apabila hal ini terusmenerus terjadi maka dapat mengakibatkan terjadinya hipertensi. Hal ini berarti menunjukkan bahwa manfaat yang didapat dari terapi SEFT dapat mengurangi resiko terkena hipertensi dengan membantu mengurangi ketegangan otot dan emosional pada penderita hipertensi. Hasil penelitian ini menunjukkan bahwa terapi SEFT berpengaruh atau memiliki efek yang positif terhadap tekanan darah.

Penelitian ini sejalan dengan penelitian Lane (2009) yang menunjukkan bahwa menstimulasi secara manual pada titik akupuntur dapat mengontrol kortisol, menurunkan rasa sakit, memperlambat denyut jantung, menurunkan kecemasan, mengontrol sistem saraf otonom sehingga dapat menciptakan rasa tenang dan rileks. Kondisi tersebut akan mempengaruhi kerja jantung dengan cara menurunkan curah jantung yang akan berimbas pada penurunan tekanan darah.
Hasil penelitian ini juga sejalan dengan penelitian yang dilakukan oleh Rofacky (2014) yang berjudul "Pengaruh Terapi SEFT Terhadap Tekanan Darah Pada Penderita Hipertensi di Wilayah Kerja Puskesmas Bergas Kecamatan Bergas Kabupaten Semarang". Hasil penelitian yang telah dilakukan pada 30 responden yang dibagi dalam dua kelompok eksperimen dan kelompok kontrol menunjukkan ada pengaruh terapi SEFT terhadap tekanan darah penderita hipertensi di Wilayah Kerja Puskesmas Bergas Kecamatan Bergas Kabupaten Semarang, dengan $p$ value $0,000<\alpha 0,05$.

Hasil penelitian ini sesuai dengan penelitian Dawson, Garret \& Audrey (2012) dalam The Journal of Nervous and Mental Disease dengan menggunakan Emotional Freedom Technique (EFT) dalam menurunkan kortisol pada stress, didapatkan hasil penelitian bahwa EFT mampu menurunkan kadar kortisol sebesar $24.39 \%$. Kadar kortisol yang menurun akan mempengaruhi kerja jantung dengan cara menurunkan curah jantung yang akan berimbas pada penurunan tekanan darah.

Penelitian lainnya yang dilakukan Zulaichah (2013) yang berjudul "Pengaruh Terapi SEFT Terhadap Penurunan Tekanan Darah Pada Lansia Hipertensi di Puskesmas Jagir Surabaya". Hasil penelitian yang telah dilakukan pada 15 responden yang dibagi dalam dua kelompok eksperimen dan kelompok kontrol menunjukkan ada pengaruh terapi SEFT terhadap tekanan darah penderita hipertensi di Puskesmas Jagir Surabaya, dengan $p$ value $0,000<\alpha 0.05$.

Penelitian lain yang juga sejalan adalah penelitian yang dilakukan oleh Nurfaridah (2012) yang berjudul "Pengaruh Terapi SEFT Islami Terhadap Tekanan Darah Pada Penderita Hipertensi Usia 45-59 Tahun di RSUD Dr. Soegiri Lamogan”. Hasil penelitian yang telah dilakukan pada 30 responden yang dibagi dalam dua kelompok eksperimen dan 
kelompok kontrol menunjukkan ada pengaruh terapi SEFT terhadap tekanan darah penderita hipertensi di RSUD Dr. Soegiri Lamogan, dengan $p$ value $0,000<\alpha 0,05$.

Hasil penelitian yang dilakukan menunjukkan bahwa terdapat pengaruh yang signifikan terhadap penurunan tekanan darah pada penderita hipertensi setelah diberikan terapi SEFT. Hasil penelitian ini menunjukkan bahwa terapi SEFT dapat menurunkan tekanan darah. Manfaat yang didapatkan dari terapi SEFT diantaranya adalah mengatasi masalah emosional dan fisik yang dapat mengontrol hormon-hormon stres seperti korsitol dan epineprin, Sehingga dapat mempengaruhi kerja jantung dan menurunkan curah jantung yang berimbas pada penurunan tekanan darah.

SEFT merupakan salah satu terapi relaksasi yang bisa dijadikan alternatif untuk menangani hipertensi. Mill (2012) menjelaskan bahwa terapi relaksasi memberikan efek sama dengan obat antihipertensi dalam menurunkan tekanan darah. Prosesnya yaitu dimulai dengan membuat otot-otot polos pembuluh darah arteri dan vena menjadi rileks bersama otototot lain dalam tubuh. Efek dari relaksasi otototot ini menyebabkan kadar neropinefrin dalam darah menurun. Otot-otot yang rileks ini akan menyebarkan stimullus ke hipotalamus sehingga jiwa dan organ dalam manusia merasakan ketenangan dan kenyamanan. Keadaan ini akan menekan sistem saraf simpatik sehingga produksi hormon epinefrin dan norepinefrin dalam darah menurun. Penurunan kadar norepinefrin dan epinefrin dalam darah menyebabkan kerja jantung dalam darahpun akan menurun sehingga tekanan darah ikut menurun.

Menurut Thayib (2010) jika menstimulasi titik-titik meridian tubuh selama 10-15 menit dan dengan intensitas ketukan yang sama mendapatkan membantu mengurangi kecemasan dan membuat perasaan menjadi lebih tenang dan nyaman, dengan menstimulasi titik-titik SEFT dapat menstimulasi pengeluaran hormon endorfin yang berfungsi sebagai hormon kebahagiaan.

Hasil penelitian ini menyimpulkan bahwa menstimulasi titik-titik SEFT pada meridian tubuh dapat mengontrol hormonhormon stres seperti korsitol dan epineprin, mengurangi kecemasan, menurunkan rasa sakit, memperlambat denyut jantung, dapat menstimulasi pengeluaran hormon endorfin yang berfungsi sebagai hormon kebahagiaan. sehingga dapat mempengaruhi kerja jantung dengan cara menurunkan curah jantung yang berimbas pada penurunan tekanan darah. dengan demikian keadaan ini akan memperluas saluran pembuluh darah yang mengalami penyempitan sehingga darah dapat mengalir dengan lancar. Dapat disimpulkan bahwa terapi SEFT dapat menurunkan tekanan darah pada penderita hipetensi.

\section{KESIMPULAN}

Berdasarkan hasil penelitian Efektivitas Terapi Spritual Emosional Fredom Technique (SEFT) Terhadap Penurunan Tekanan Darah Pada Penderita Hipertensi maka dapat disimpulkan:

1. Pada kelompok eksperimen sebelum dilaksanakan intervensi terapi SEFT didapatkan nilai MAP sebesar 118,37 dan pada kelompok kontrol didapatkan nilai MAP sebesar 120,93.

2. Pada kelompok eksperimen sesudah dilaksanakan intervensi terapi SEFT didapatkan nilai MAP sebesar 101,23 dan pada kelompok kontrol didapatkan nilai MAP sebesar 120,23.

3. Terapi SEFT efektif dalam menurunkan tekanan darah pada penderita hipertensi.

\section{SARAN}

1. Bagi Institusi Pendidikan 
Daharapkan bagi institusi pendidikan khususnya bagi mahasiswa dan mahasiswi keperawatan STIKes Al-Insyirah Pekanbaru dapat dijadikan sebagai informasi baru dan sebagai bahan bacaan pada kepustakaan khususnya pada mata ajar terapi komplementer.

2. Bagi Tempat Penelitian (Puskesmas)

Diharapkan hasil penelitian ini dapat dijadikan bahan kajian dalam rangka menentukan kebijakan dan langkahlangkah yang berkaitan dengan penanggulangan masalah hipertensi di Puskesmas Harapan Raya Pekanbaru. Selain itu, dapat menjadi masukan bagi Puskesmas Harapan Raya Pekanbaru untuk menggunakan terapi SEFT sebagai salah satu terapi komplementer dan sebagai terapi inovatif keperawatan untuk menurunkan tekanan darah pada penderita hipertensi.

3. Bagi Peneliti Selanjutnya

Diharapkan kepada peneliti selanjutnya agar ada tindak lanjut untuk melakukan observasi terhadap pola makan, aktivitas olahraga dan faktor-faktor lain yang dapat meningkatkan tekanan darah.

\section{DAFTAR PUSTAKA}

Braverman, E., \& Braverman, D. (2008). Penyakit jantung dan penyembuhannya secara alami (A. Rahmalia, Terj). Jakarta: PT Bhuana Ilmu Populer.

Dinkes Kota Pekanbaru. 2015. Data jumlah penderita hipertensi. Rekam Medis.

Dawson, dkk. 2012. The Effect of Emotional Freedom Techniques on Stress Biochemistry: A Randomized Controlled Trial : The Journal of Nervous and Mental diperoleh dari http://www.eftuniverse.com/researchand-studies/the-effect-of-emotional- freedom-techniques-eft-on-stressbiochemistry.

Lane, J. 2009. The Neurochemistry Of Counterconditioning: Acupressure Desensitization In Psychotherapy.

Lumbantobing, S.M. 2008. Tekanan darah Tinggi. Balai Penerbit FK UI, Jakarta.

Mills, Chaterin J. A . 2012. Comparision of Relaxation Techniques on Blood Preassure Reactivity and Recovery Assessing The Moderating Effect of Anger Coping Style. Dissertation Old Dominion University.

Nurfaridah, V. 2012. Pengaruh Terapi Spiritual Emotional Freedom Technique (SEFT) Islami Terhadap Tekanan Darah Pada Penderita Hipertensi Usia 45-59 Tahun di RSUD Dr. Soegiri Lamogan. Skripsi Program Studi Ilmu Keperawatan Universitas Lamongan .

Riskesdas. 2013. Riset Kesehatan Dasar. http://www.depkes.go.id/resources/do wnload/general/Hasil\%20Riskesdas\%2 02013.

Thayib, S. 2010. Preview Spiritual Emotional Freedom Technique, Surabaya : LoGOS Institute.

Rofacky. 2014. Pengaruh Terapi Spiritual Emotional Freedom Technique (SEFT) Terhadap Tekanan Darah Pada Penderita Hipertensi di Wilayah Kerja Puskesmas Bergas Kecamatan Bergas Kabupaten Semarang. http://perpusnwu.web.id/karyailmiah/ documents/3847.pdf .

Smeltzer. S. C., \& Bare, B. G. (2004). Buku Ajar Keperawatan Medikal-Bedah Brunner \& Suddart Ed 8 Vol 2. Jakarta: EGC.

Zainuddin, A. F. 2009. Spiritual Emotional Freedom Technique. Jakarta: Afzan Publishing. 
Zulaichah, S. 2013. Pengaruh Terapi Spiritual Emotional Freedom Technique (SEFT) Terhadap Penurunan Tekanan Darah
Pada Lansia Hipertensi di Puskesmas Jagir Surabaya.

Skripsi

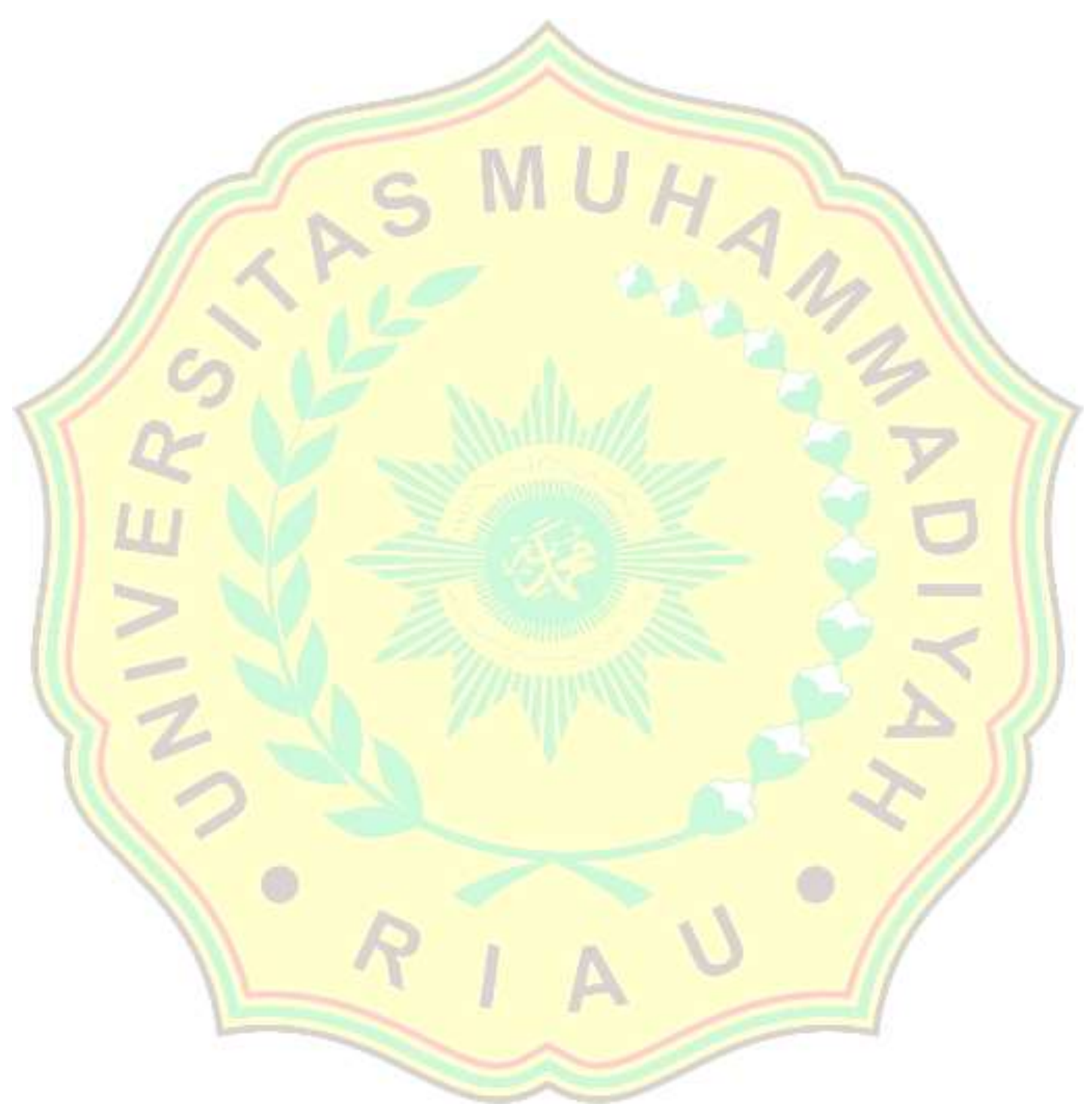

